Note: Snapshot PDF is the proof copy of corrections marked in EditGenie,
the layout would be different from typeset PDF and EditGenie editing view. Author Queries \& Comments:

AQ1: There is discrepancy in the author surname between the manuscript and cats.xml. We have followed the manuscript. Please check.

Response: Resolved

AQ2: Please note that the ORCID has/have been created from information provided through CATS. Please correct if this is inaccurate.

Response: Resolved

AQ3: As abstracts are published standalone, we have replaced the reference citation with complete details of the reference. Please confirm if this is okay.

Response: Resolved

AQ4: Please note that the Funding section has been created from information provided through CATS. Please correct if this is inaccurate.

Response: Resolved

AQ5: The funding information provided (the Spanish Ministerio de Economia y Competitividad) has been checked against the Open Funder Registry and we found a partial match with "Ministerio de Economia y Competitividad". Please check and resupply the funding details.

Response: Resolved

AQ6: The funding information provided (Projectes d'Innovació Educativa de la Unitat de Suport Educatiu) has been checked against the Open Funder Registry and we failed to find a match. Please check and resupply the funding details. Response: Resolved

AQ7: The reference "AUTHOR \& AUTHOR, 2016" is cited in the text but is not listed in the references list. Please either delete the in-text citation or provide full reference details following journal style.

Response: This citation appears in the referelence list as Martí \& Portolés (2016).

AQ8: The reference "AUTHOR, 2014" is cited in the text but is not listed in the references list. Please either delete the in-text citation or provide full reference details following journal style.

Response: This in-text citation appears in the reference list as Portolés (2014).

AQ9: The reference "Chiva and Chostelidou (2012)" is cited in the text but is not listed in the references list. Please either delete the in-text citation or provide full reference details following journal style.

Response: Sorry. There was a spelling mistake. It is Griva instead of Chiva.

AQ10: The disclosure statement has been inserted. Please correct if this is inaccurate.

Response: Resolved

AQ11: The CrossRef database (www.crossref.org/) has been used to validate the references. Mismatches between the original manuscript and CrossRef are tracked in red font. Please provide a revision if the change is incorrect. Do not comment on correct changes

Response: Resolved

AQ12: Please provide missing volume number for reference "Karavas and Drossou, 2010" references list entry. Response: Sorry. This is a book chapter. Karavas, E., \& Drossou, M. (2010). How amenable are student teacher beliefs to change? A study of EFL student teacher beliefs before and after teaching practice. In A. Psaltou-Joycey \& M. Matheoudakis (Eds.), Advances in research on language acquisition and teaching: Selected papers (pp. 261-276). Thessaloniki:Greek Applied Linguistic Association.

AQ13: The reference "Martí and Portolés, 2016" is listed in the references list but is not cited in the text. Please either cite the reference or remove it from the references list. 
AQ14: Please provide missing volume number for reference "Otwinowska, 2017" references list entry.

Response: Resolved

AQ15: The reference "Portolés, 2014" is listed in the references list but is not cited in the text. Please either cite the reference or remove it from the references list.

\title{
Teachers' beliefs about multilingual pedagogies and the role of initial training
}

\author{
Recto running head : INTERNATIONAL JOURNAL OF MULTILINGUALISM \\ Verso running head : L. PORTOLÉS AND O. MARTÍ \\ (iDLaura Portolés ${ }^{\mathrm{a}}$ [AQ1], (D) Otilia Martí ${ }^{\mathrm{b}}$ [AQ2]
}

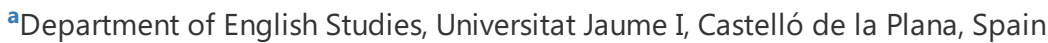

${ }^{b}$ Department of Pedagogy, Universitat Jaume I, Castelló de la Plana, Spain

CONTACT Laura Portolés Iportole@uji.es

History : received : 2018-06-06 accepted : 2018-08-20

Copyright Line: (c) 2018 Informa UK Limited, trading as Taylor \& Francis Group

\begin{abstract}
Teacher training programmes have often ignored the new multilingual paradigm and, consequently, educators may hold some misconceptions about how additional languages are learnt and should be taught in multilingual contexts. A number of recent studies have investigated language teachers' beliefs regarding multilingual education [Arocena-Egaña, E., Cenoz, J., \& Gorter, D. (2015). Teachers' beliefs in multilingual education in the Basque country and in Friesland. Journal of Immersion and ContentBased Language Education, 3(2), 169-193; De Angelis, G. (2011). Teachers' beliefs about the role of prior language knowledge in learning and how these influence teaching practices. International Journal of Multilingualism, 8(3), 216-234; Griva, E., \& Chostelidou, D. (2012). Multilingual competence development in the Greek educational system: FL teachers' beliefs and attitudes. International Journal of Multilingualism, 9(3), 257-271; Haukås, Å. (2016). Teacher's beliefs about multilingualism and a multilingual pedagogical approach. International Journal of Multilingualism, 13(1), 1-18; Mitits, L. (2018). Multilingual students in Greek school: teachers' views and teaching practices. Journal of education and e-learning research, 5(1), 28-36. Otwinowska, A. (2014). Does multilingualism influence plurilingual awareness of Polish teachers of English? International Journal of Multilingualism, 11(1), 97-119]. Unlike this extant literature, the current paper focuses not on language teachers, but on a sample of 121 subject teachers-to-be. More specifically, it aims to explore preschool and primary prospective teachers' beliefs about the learning and teaching of English as an L3 in the Valencian Community. The main data collection tool was a questionnaire, partially based on [Griva, E., \& Chostelidou, D. (2012). Multilingual competence development in the Greek educational system: FL teachers' beliefs and attitudes. International Journal of Multilingualism, 9(3), 257-271] semi-structured interviews. This questionnaire was implemented as a pretest and as a posttest in order to analyse the effect of instruction for multilingual education on subject teachers' beliefs. Results point to the effectiveness of initial teacher training on tertiary/additional language teaching. However, they also confirm the persistence of some monolingual views concerning key issues, such as the younger-the better myth, as already highlighted in previous studies conducted in similar multilingual contexts (see Arocena-Egaña, E., Cenoz, J., \& Gorter, D. (2015). Teachers' beliefs in multilingual education in the Basque country and in Friesland. Journal of Immersion and Content-Based Language Education, 3(2), 169-193].[AQ3]
\end{abstract}

\section{KEYWORDS}

Multilingual education; multilingual pedagogies; tertiary/additional language didactics; EAL; pre-service subject teachers' beliefs; initial teacher training

\section{FUNDING}

[AQ4]This work was supported by the Spanish Ministerio de Economia y Competitividad: [grant number FFI2016-78584-P]; [AQ5] Projectes d'Innovació Educativa de la Unitat de Suport Educatiu: [grant number 3457/17]; [AQ6]Universitat Jaume I: [grant number P1ÂA.1B2015-20, E-2015-03 and E-2015-30].

\section{Introduction}

The change of paradigm from a traditional second language acquisition (henceforth SLA) approach to a third language acquisition one (henceforth TLA) has contributed enormously to developing the field of multilingual research. The rise of multilingual programmes through the early teaching of English or the incorporation of minority and migrant languages in school settings has been one of the main educational trends observed over the last decades. However, European teacher training 
programmes in current language pedagogies have neglected the multilingual factor (De Angelis, 2011) or have been mostly dominated by the English-only policy (Otwinowska, 2017). As a result of this lack of training in tertiary or additional language didactics, teachers may hold some preconceived views about teaching and learning multiple languages.

Existing research in multilingual settings has already analysed in-service teachers' beliefs about L3 learning and teaching (Arocena-Egaña, Cenoz, \& Gorter, 2015; De Angelis, 2011; Griva \& Chostelidou, 2012; Haukås, 2016; Heyder \& Schädlich, 2014; Mitits, 2018; Otwinowska, 2014). Yet, as far as we know, novice preschool and primary education teachers' beliefs about multilingual education are mostly unexplored. It seems relevant, then, to see whether their views are in line with those reported in the available literature. Additionally, our study intends not only to explore prospective teachers' beliefs about L3 learning and teaching but also to ascertain the impact of multilingual didactics instruction on those issues. In that vein, we compare teachers' beliefs before and after an initial teacher training course about how to teach English from a multilingual perspective.

\section{Multilingual education}

The coexistence and interaction of languages is a natural phenomenon in our globalised society. Multilingualism is the norm in almost every single country in the world and current governments are challenged to implement multilingual policies in educational settings. In Europe, transnational agencies, such as The European Commission, encourage all their citizens to learn their mother tongue and at least two additional languages. As a result, multilingual education programmes have been on the rise in the last two decades. As proposed by Cenoz and Gorter (2015, p. 2), multilingual education could be defined as 'the use of two or more languages in education, provided that schools aim at multilingualism and multiliteracy'. In the case of Spain, where several first languages officially coexist in its bilingual regions, multilingual programmes combine the use of the national state language (i.e. Spanish), the regional language (e.g. Catalan in the Valencian Community) and the international language of communication (i.e. English).

The emergence of multilingual education all over the globe has promoted (i) the introduction of English as an additional language (henceforth EAL) from a very early age, (ii) the teaching of English through content, a pedagogical approach known as Content and Language Integrated Learning or CLIL, and (iii) the learning of minority and migrant languages. These educational trends have been accompanied by an extensive body of research in the field of TLA which has steadily abandoned the monolingual viewpoint of mainstream SLA research. Recent studies (e.g. Cenoz \& Gorter, 2015; Kirsch, 2017; Portolés \& Martí, 2017; Safont \& Portolés, 2016) have suggested that multilingual speakers use their whole language repertoire as a continuum in order to communicate strategically and effectively. This is what is known as translanguaging (see Cenoz \& Gorter, 2017; García \& Wei, 2014; or Lewis, Jones, \& Baker, 2012). In fact, TLA research has demonstrated the facilities of multilingual learners in comparison to monolingual ones in several areas like pragmatic awareness (Alcón-Soler, 2012; Portolés, 2015; Safont \& Portolés, 2016). When English teachers' language awareness is raised to make them more conscious of the benefits of adopting a crosslinguistic approach, their students' language learning process may be also boosted (Otwinowska, 2017).

Unfortunately, current pedagogical practices still adopt monolingual principles. In fact, it seems that findings derived from research on TLA and multilingualism have been only partially translated into teachers' classroom behaviour. As a result, widely spread language teaching approaches are still grounded on a monolingual bias and languages are conceived as separate entities and, consequently, taught separately. In Inbar-Lourie's words (2010, p. 351), 'language teaching pedagogy has tended to ignore or even suppress bilingual or multilingual options endorsing a predominantly monolingual policy, one which equates 'good teaching' with exclusive or nearly exclusive target language use'. Consequently, the use of several languages in the foreign language classroom has been avoided in order to prevent what is perceived as cross-linguistic 'contamination'. Furthermore, the attainment of an ideal native speaker's competence has become the goal of most language programmes, although recent research has already proven the benefits of translanguaging and the advantages of instruction through minority and foreign languages (see Cenoz, 2017, for an overview).

All these valuable insights from research on multilingualism should be incorporated in initial teacher training programmes since most language and generalist or subject teachers may otherwise adopt a monolingual viewpoint in the classroom. As suggested by Otwinowska (2017), English teachers who benefit from their previous experience as multilingual language learners and/or are trained in accordance to multilingual pedagogies will become more successful in their teaching practices. However, a significant number of educators are not yet familiar with the most recent literature in the field. Hence, current multilingual school practices would adopt monolingual principles inasmuch many teachers' views might still be based on a traditional SLA perspective. Existing well-established beliefs, which are widespread assumptions in education, appear to be difficult to remove easily, as explained in the next section.

\section{Teachers' beliefs about multilingual education}

Teachers' beliefs are included in a broader area of study known as teacher cognition, which has become an important research focus. Teacher cognition could be seen as an umbrella term that refers to teachers' mental lives. More specifically, this concept embraces what teachers think, know and believe. According to Borg (2003), teacher cognition addresses the cognitive dimension of teaching and includes the beliefs held by teachers about learning and teaching practices. This cognitive dimension is not directly observable, but plays a pivotal role in teachers' professional lives. The study of teacher cognition gained importance four decades ago when researchers found that teachers' own beliefs had a significant impact on how they actually behaved in the classroom (Pajares, 1992).

Beliefs are related to attitudes because they represent the cognitive component of the attitude construct and could be defined as 'propositions individuals consider to be true and which are often tacit, have a strong evaluative and affective content, provide a 
basis for action, and are resistant to change' (Borg, 2011, p. 370). In other words, beliefs represent a set of views, perceptions, or propositions felt by a person to be true (Richardson, 1996). It is generally acknowledged that teachers' beliefs may have emerged and then established throughout their schooling (Pajares, 1992). This is what Lortie (1975) coined as 'apprenticeship of observation'. This set of beliefs may be seen as educators' initial perceptions about teaching and learning, which are based on their extensive learning experiences as pupils, and, consequently, are likely to influence their future professional practices. To exemplify this, if a teacher believes that languages should be taught in isolation, s/he is likely to forbid bringing other languages to the English classroom.

The role played by initial teacher training programmes may be crucial for reshaping prospective teachers' perceptions and/or misconceptions. Some studies (Abasifar \& Fotovatnia, 2015; Karavas \& Drossou, 2010; Peacock, 2001) have concluded that ESL/EFL pre-service teachers' beliefs may not change after completing their formation as teacher trainees, while other studies (Cabaroglu \& Roberts, 2000; Debreli, 2012) have reported the effectiveness of instruction on their participants' views after some training period. Thus, results about the impact of teacher training courses on $L 2$ teachers' beliefs seem rather inconclusive. As far as we know, the influence of initial training about tertiary/additional language didactics on teachers' beliefs has received little attention.

Extensive research on teachers' beliefs has explored issues related to grammar in ESL and EFL contexts (see Borg, 2003 for a revision). To date, though, very few studies have investigated teachers' beliefs about L3 language learning and teaching in multilingual contexts (De Angelis, 2011; Griva \& Chostelidou, 2012; Haukås, 2016; Heyder \& Schädlich, 2014; Mitits, 2018; Otwinowska, 2014). More specifically, those studies have been conducted in different European countries, like Italy, Great Britain and Austria (De Angelis, 2011), Norway (Haukås, 2016), Poland (Otwinowska, 2014, 2017), Germany (Heyder \& Schädlich, 2014) and Greece (Griva \& Chostelidou, 2012; Mitits, 2018). Findings reported by the aforementioned literature show that in-service secondary school teachers coincide in stating that knowing languages is positive and also acknowledge the benefits of being multilingual. However, these results also suggest that when educators face the reality of the classroom, their practices are still based on widespread monolingual beliefs (e.g. the belief that target languages must be taught in isolation, the belief that language teachers should behave like a monolingual native speaker and/or the belief that the earlier English is introduced, the better).

Furthermore, most contributions discussed above have explored language teachers' cognition in the case of secondary schools around Europe. As far as we know, the research conducted by Arocena, Cenoz and Gorter (2015) is the only one centred on inservice primary school teachers in the Basque Country and Friesland. Yet, findings from practitioners' beliefs in Basque and Frisian primary schools also confirm the continuance of some monolingual views at this educational level (see Arocena-Egaña et al., 2015, pp. 188-189). Such persistence, then, may derive from traditional teacher training degrees in which key aspects about tertiary/additional language didactics are systematically ignored or neglected in their course contents (De Angelis, 2011).

In sum, the vast majority of studies on teachers' beliefs about multilingual education have focused, so far, on experienced language practitioners mostly in secondary and, exceptionally, in primary education. Little is known, on the one hand, about prospective content teachers' beliefs in how to teach EAL at a preschool or primary educational levels; and, on the other hand, about the effect of initial training on such beliefs. Taking into account those research gaps, the aim of the present study is twofold. First, to identify pre-service content teachers' beliefs, in order to ascertain the extent to which they conform to or differ from the insights derived from current research on multilingual education. Second, to investigate the impact of initial training on our respondents' beliefs, in order to distinguish between those that are still malleable versus the ones that prove more resistant to change.

\section{Research questions}

Taking into account both findings from previous research and the main goals stated above, the research questions that guide the present study are the following:

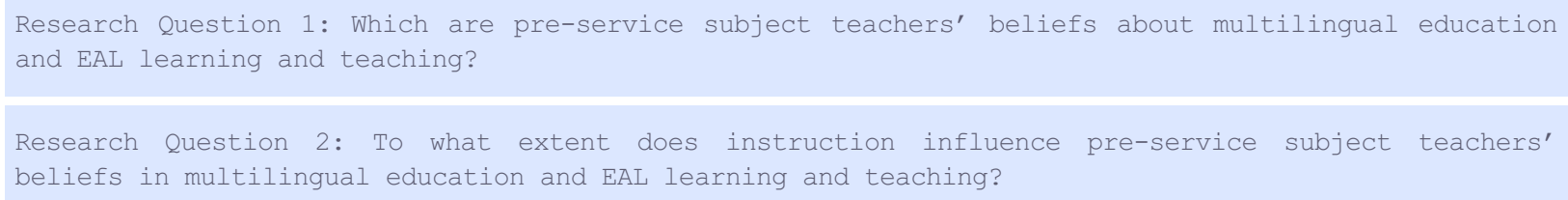

\section{Method}

\section{Participants}

The sample consisted of 121 pre-service teachers whose mean age was 20.5. Regarding their gender distribution, 90.9\% were female $(n=110)$ and $9.1 \%$ were male $(n=11)$. While $53.7 \%$ of them $(n=65)$ were trained as infant or preschool teachers, $46.3 \%$ of the sample $(n=56)$ were studying to become primary teachers. Participants in both groups were trained to work as generalists or subject teachers. In terms of their mother tongue, $53.7 \%$ of the students $(n=65)$ reported to be native speakers of Catalan, followed by Spanish ( $n=53,43.8 \%$ ); and, Romanian ( $n=3,2.5 \%)$. Regardless their mother tongue, all participants were able to understand both official languages, Spanish and Catalan.

Respondents were enrolled in a state-funded university located on the east coast of Spain, in the Valencian Community. This is a bilingual community where Catalan and Spanish coexist as official languages and English is learnt as a third or as an additional 
language. Currently, the Valencian school system offers multilingual programmes in which the three languages are used as vehicular in content subjects. However, our participants had not experienced being taught through English in primary and secondary education. English was exclusively implemented as a language subject when they were schooled. Their first experience with CLIL lessons took place throughout the common course 'English Language Teaching' in the third year of the Bachelor's Degrees in Preschool Education and in Primary Education.

\section{Instrument}

As the main research instrument, we designed and implemented a questionnaire, which was partially based on Griva and Chostelidou's (2012) semi-structured interviews. Ours was written in Catalan and its validity tried out in a pilot study (see Martí AUTHOR \& PortolésAUTHOR, 2016[AQ7]). The questionnaire was divided into two parts. The first part gathered background information about the respondents, such as gender, mother tongue, previous schooling and English proficiency level, among others. The second section comprised a total of 30 items distributed into six main thematic strands, identified as paramount in multilingualism research: (i) status of European languages, status of English and multilingual policy in Europe, (ii) ways of enhancing multilingual education, (iii) benefits of multilingualism and the notion of multicompetence, (iv) early foreign language learning, (v) forms of immersion in English; and, (vi) ideal multilingual teacher's profile and their professional development. The instrument consisted of a five-point Likert-type scale with the following descriptors: Strongly Agree, Agree, Neither Agree Nor Disagree, Disagree and Totally Disagree.

\section{Procedure and data analysis}

The data collection tool described above was implemented as a pretest and as a posttest in the course 'English Language Teaching'. This is a first-term compulsory subject which aims to provide teacher trainees with the foundations for introducing English as the language of instruction in preschool and primary education. The course syllabus revolves around, first, how the target language has to be taught in multilingual contexts and, second, the need to integrate languages and contents. To do so, the syllabus attempts to fill the gap between a traditional SLA perspective and current research findings on TLA and multilingual education. Activities include lecturing and students' active learning through class debates, small group discussions and individual essays. All the aspects tackled in the questionnaire are included in the course contents. Students received 12 lectures that represent 18 contact hours at class and $6 \mathrm{~h}$ approximately of reading about the topic at home.

The questionnaires were distributed and completed at the end of a regular in-class session before and after the treatment (i.e. instruction). Attendees were kindly requested to respond sincerely on the answer sheets and the time allowed to do so was 30 min. They were asked to tick their degree of agreement or disagreement with each item in the questionnaire. The scores obtained were codified thus: the option Strongly Agree (SA) was recorded as 100, the option Agree (A) as 75, Neither Agree Nor Disagree (NAND) as 50, Disagree (D) as 25 and Totally Disagree (TD) as 0 . The resulting means were employed in order to handle Research Question 1 as they illustrated the level of agreement towards each questionnaire item.

With regard to Research Question 2, respondents' initial beliefs collected prior to instruction were compared with those held after it, to find whether such beliefs were in line or not with the existing literature on multilingual education presented in class. In order to respond to this second research question, all negatively worded statements were reversely scored. Hence, every 100 score implies full knowledge about multilingualism. For estimating the impact of instruction, a paired-samples $t$-test was conducted to note the scores in the pretest and the posttest for each thematic strand. This test helped us to compare the before and after instruction scores from the same group at different times. Finally, data were measured statistically by means of the Statistical Package for the Social Sciences or SPSS programme. Significance was always considered at the level of 0.05.

\section{Results and discussion}

\section{Results and discussion related to research question 1}

The first research question explored teacher trainees' initial beliefs about the following thematic strands: (1) status of European languages, status of English and multilingual policy in Europe, (2) ways of enhancing multilingual education, (3) benefits of multilingualism and the notion of multicompetence, (4) early foreign language learning (e.g. the best age for introducing Englishmedium instruction in school settings), (5) forms of immersion in English: how much instructional time; and, (6) the ideal multilingual teacher's profile and their professional development. We wondered whether those beliefs were in line with previous findings from the fields of multilingualism, TLA and very early English language teaching/learning. The Figures below show the respondents' level of agreement or disagreement on a Likert scale for a series of statements. Thus, the mean illustrates the intensity of their beliefs for a given item, being 100 the highest level of agreement while 0 score is the lowest level of agreement with each statement.

Starting with the first thematic strand and as can be seen in Figure 1, pre-service subject teachers embrace a firmer multilingual policy in Europe since most of them back the promotion of lesser-used and/or minority European languages such as Catalan and Basque $(M=71.69 ; \mathrm{SD}=24.56)$ and support the necessity of developing communicative ability in at least two foreign languages $(M=64.26 ;$ SD = 27.54). Most respondents also acknowledge the urge for every European citizen to learn English $(M=74.17 ; S D=$ 21.87). Yet, the supremacy of English as the only lingua franca in Europe is questioned ( $M=60.54 ; S D=24.73)$, with almost $25 \%$ of participants challenging its status. Besides, more than $30 \%$ of the subjects do not believe that some languages are more useful than others $(M=60.12 ;$ SD $=24.73)$.

Figure 1. Means of teachers' beliefs about the multilingual policy in Europe (1st thematic strand). 


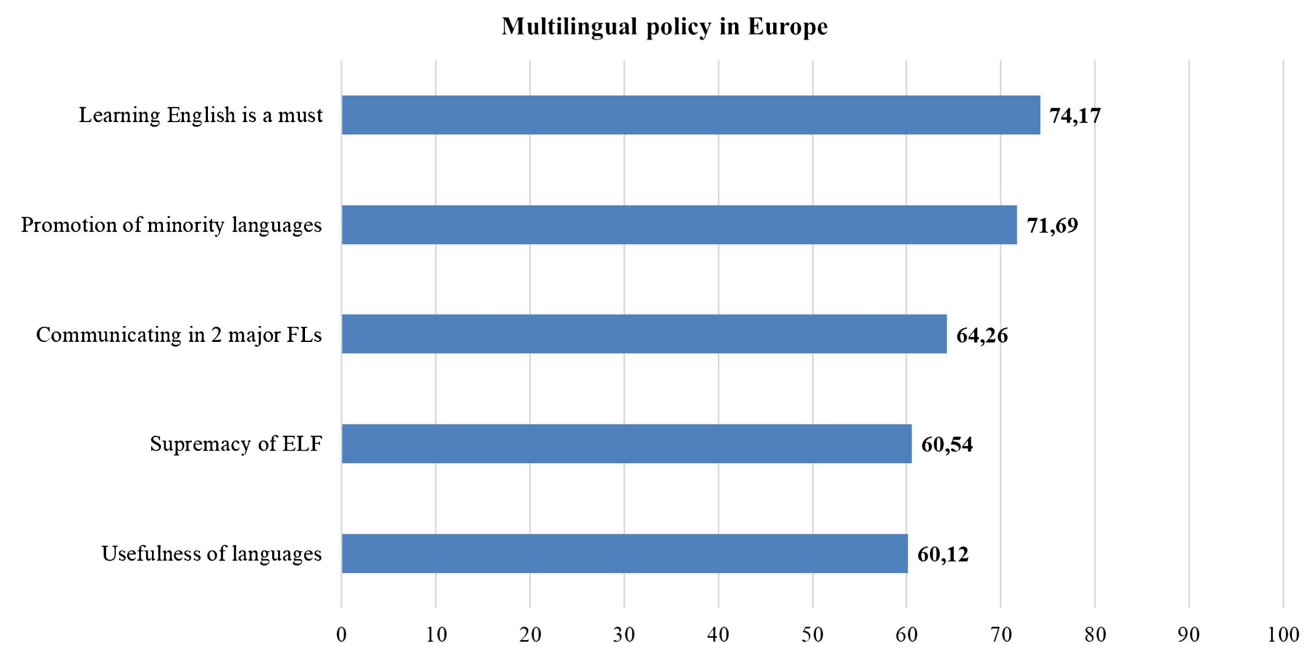

Contrary to previous findings (Griva \& Chostelidou, 2012), then, a significant part of our respondents express a higher support to minority languages and challenge the extended belief that some languages are more useful than others. The reasons behind these results might be related to the rich sociolinguistic milieu that the Valencian Community offers, with several languages coexisting both in and out of school. Recent studies (MartíAUTHOR \& PortolésAUTHOR, 2016; PortolésAUTHOR, 2014[AQ8]) have also pointed out that prospective Valencian teachers view multilingualism as an asset and report cultural and emotional ties to the minority language (i.e. Catalan). Additionally, undergraduate students enrolled in Teacher Training Degrees tend to value languages, regardless of their status and perceived usefulness. Actually, despite the increasingly presence of English and its prestige, our participants think that learning this foreign language is a must for every European citizen, but some of them contest its supremacy as a lingua franca.

Other answers within this first thematic strand also suggest that pre-service teachers' beliefs about multilingual policy in Europe are in line with the European Commission's language formula according to which all their citizens should learn their mother tongue and at least two other languages. This stance is further described and elaborated in next Figure about multilingual education and ways of enhancing it.

As illustrated in Figure 2, findings regarding the second thematic strand show that prospective teachers strongly agree in that minority or regional languages should be promoted $(M=87.80 ; S D=16.80)$ and consider that at least two foreign languages should be included in the school curriculum $(M=82.02 ; \mathrm{SD}=18.60)$. However, they are more sceptical about the introduction of non-European member languages at schools $(M=52.48$; $S D=22.68)$ and, more specifically, about fostering the teaching of migrant children's mother tongues $(M=50.00 ; S D=27.95)$.

Figure 2. Means of teachers' beliefs about multilingual education and ways of enhancing it (2nd thematic strand).

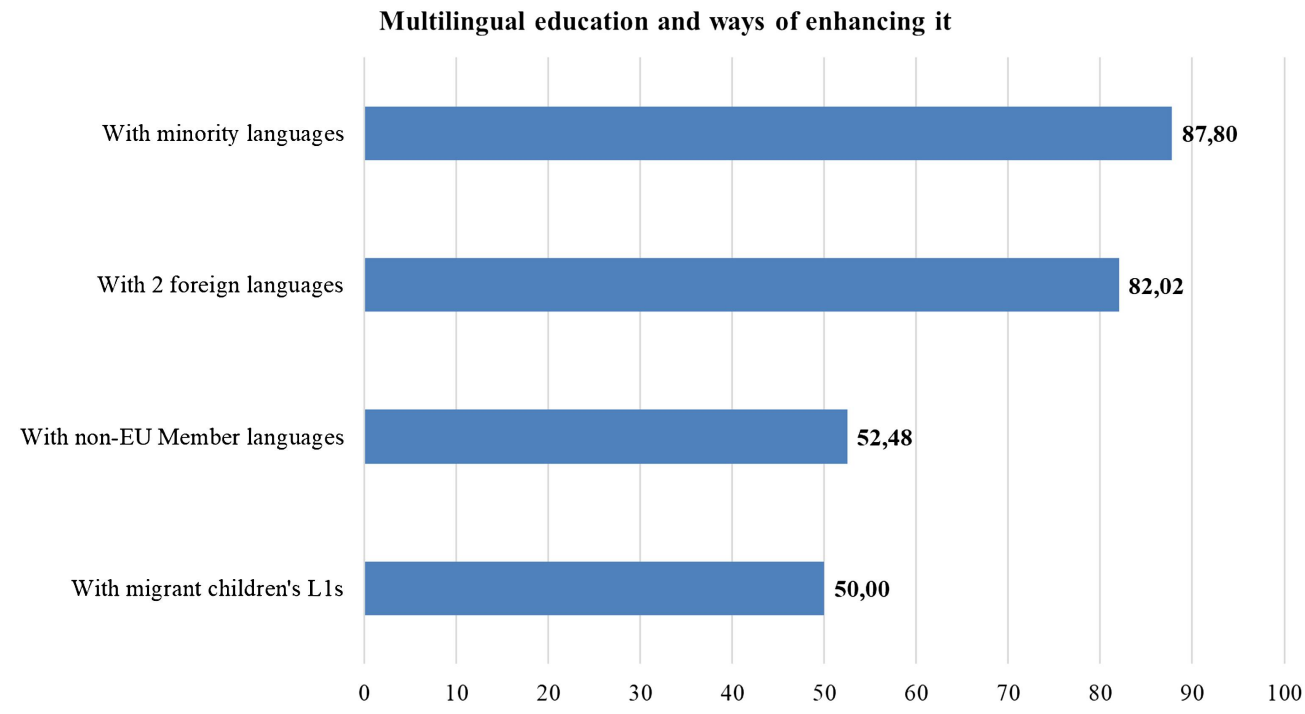

Although 93.3\% of the participants in our study favour the learning of Catalan as the best way to achieve a multilingual education, they also support, in line with GrivaChiva and Chostelidou (2012[AQ9], p. 261), the introduction of two European foreign languages that enjoy a high sociocultural status as is the case of French and German. Nevertheless, only 41 respondents (33.8\%) insist on the learning of migrants' L1s (Arabic and Romanian in the Valencian Community), as well as on initiating the teaching of non-European Member languages like Russian and Chinese. We may argue, then, that, generally speaking, our participants favour the promotion of multilingual education, but there is still a lot of work to be done to gain the full acceptance of migrant languages. The presence of Romanian and Arabic populations at Valencian schools is high and teachers tend to integrate children's home languages through the linguistic landscape and storytelling. All in all, the use of those languages in teaching within the school schedule is very limited. 
The third main thematic strand deals with the notion of multicompetence. As seen in Figure 3, our participants strongly agree with the statement that being multilingual has cognitive advantages $(M=86.57$; SD $=16.47)$. In parallel, they disagree with the view that learning more than one language at the same time is harmful $(M=22.73$; SD $=19.09)$ or the notion that multilingual learners should learn one language at a time $(M=28.10 ; S D=21.78)$. Yet, Figure 3 below also shows that half of the respondents believe that having a high proficiency level in all the languages of one's linguistic repertoire is necessary in order to become multilingual $(M=52.07 ; \mathrm{SD}=27.30)$.

Figure 3. Means of teachers' beliefs about the notion of multicompetence (3rd thematic strand).

\section{The notion of multilcompetence}

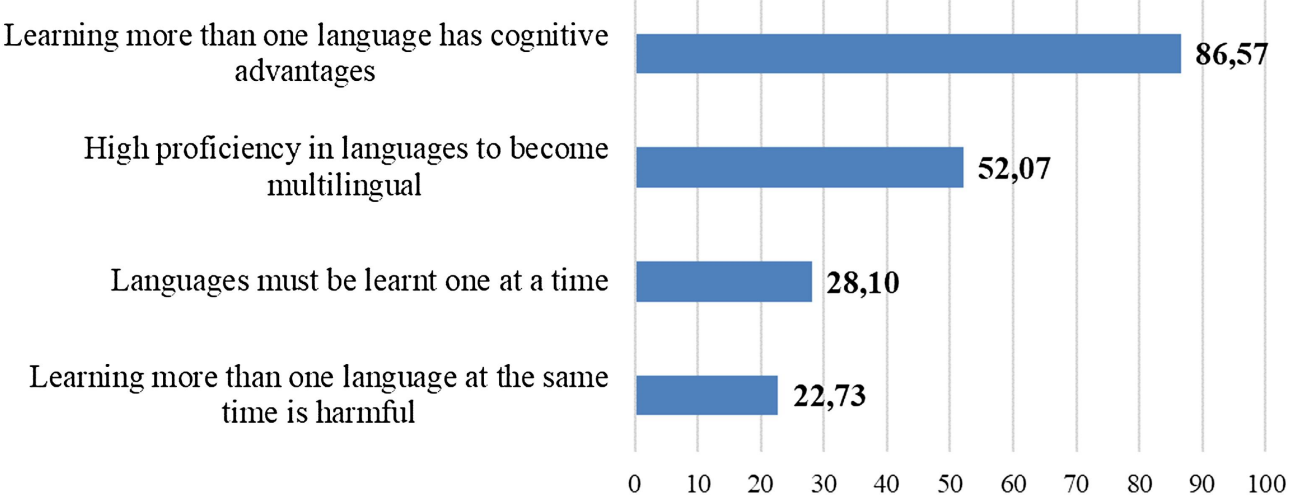

While $94.1 \%$ of the participants acknowledge the cognitive advantages of being multilingual, $84.3 \%$ of them state that learning more than one language at the same time has no harmful effects on learners' overall linguistic competence; and $81.8 \%$ disagree on the need to learn one language at a time, it is worth noting that $42.9 \%$ of the subjects still think that multilinguals have to reach a very high proficiency level in all the languages they employ. The perception that being in full command of every single linguistic variety in one's verbal repertoire is a must to become multilingual has prevailed for decades. This belief results from having set the native speaker as a model to measure competence in any language, an idealisation or construct that has been challenged as an unattainable goal or, even, as a myth (Davies, 2003). Instead, concepts like those of multicompetence or L2 language user coined by Cook (1991, 1992, 2007), and further developed from an English as a Lingua Franca or ELF perspective (see Llurda, 2009, 2016), establish that real multilinguals are successful communicators in their own right without needing to reach the same proficiency level in all the languages they speak, because each linguistic variety in their verbal repertoire fulfils a purpose, function or use.

Moving on to the fourth thematic strand on early language learning and the best age to implement English-medium instructional approaches, Figure 4 indicates that many would-be teachers feel that there are opportunities for lifelong foreign language learning $(M=77.27 ; \mathrm{SD}=24.36)$ and that most of them also consider that young learners can learn English easily and quickly $(M=$ 83.47; SD = 18.41). Accordingly, regarding the best age to introduce English as a medium of instruction, the first choice is introducing English in preschool $(M=87.60 ; S D=18.57)$, followed by doing so at the beginning of primary school $(M=41.95 ; S D$ = 29.96). Yet, very few respondents opt for upper primary education $(M=19.42 ; S D=20.78)$.

Figure 4. Means of teachers' beliefs about early language learning (4th thematic strand).

\section{Early language learning}

Introducing English in pre-school (at the age of 3)

Young children can learn easily and quickly

There are opportunities for lifelong FL learning

Early Language Learning contributes to long-term academic success

Introducing English in primary school (at the age of 6 )

Introducing English in late primary school (at the age of 11)

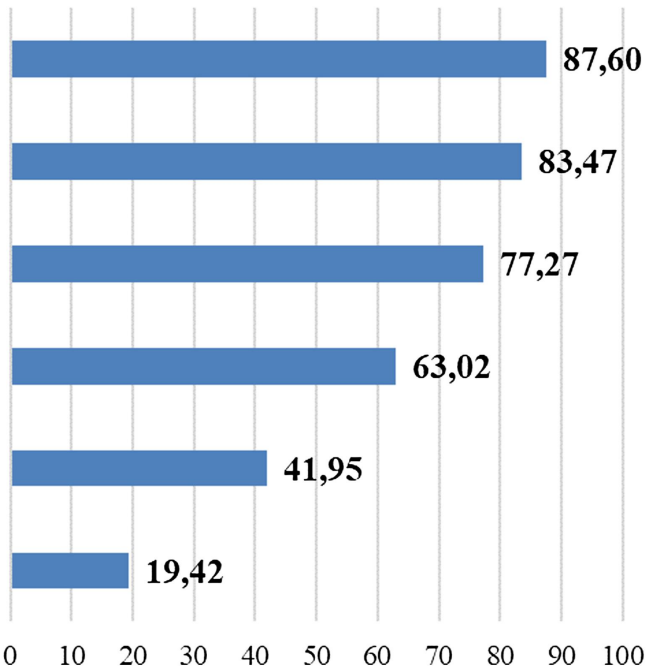

Although the majority of interviewees in Chiva and Chostelidou's study (2012, p. 266) also showed positive attitudes towards very early English language learning, Valencian respondents agree even more on the 'younger = better' premise. Hence, our 
participants' clear preference for introducing English in kindergartens is stronger as they claim that English-medium instructional approaches should start to be implemented with 3-year-old children, while the Greek teachers opted for the age of five and six. This finding may be linked to the prevailing belief that children are like sponges and the sooner they start learning a foreign language, the better.

When attention is paid to the best form of immersion in English (i.e. the fifth thematic strand), Figure 5 displays means that are always inferior to 50.00, what might be interpreted as pre-service subject teachers losing conviction or remaining undecided. In contrast, respondents seem to agree on one point: the traditional English as a Foreign language classroom is not enough to learn this language $(M=18.18$; SD = 17.97), a view that might derive from Spanish students' poor results and their consequent disappointment in the country's formal education system. Surprisingly enough, among the alternatives, stay-abroad periods are not regarded as an essential requirement to attain high levels of proficiency in English $(M=19.21$; $S D=16.69)$. Regarding how much instructional time participants considered to be adequate, stronger forms of immersion like English speaking schools are slightly favoured $(M=44.01 ; S D=27.95)$, followed by immersion at home $(M=38.22 ; S D=25.42)$ along with milder versions of immersion like CLIL in subjects such as Arts and Crafts or Science $(M=35.74$; SD $=25.17)$.

Figure 5. Means of teachers' beliefs about forms of immersion in English (5th thematic strand).

\section{Forms of immersion in English}

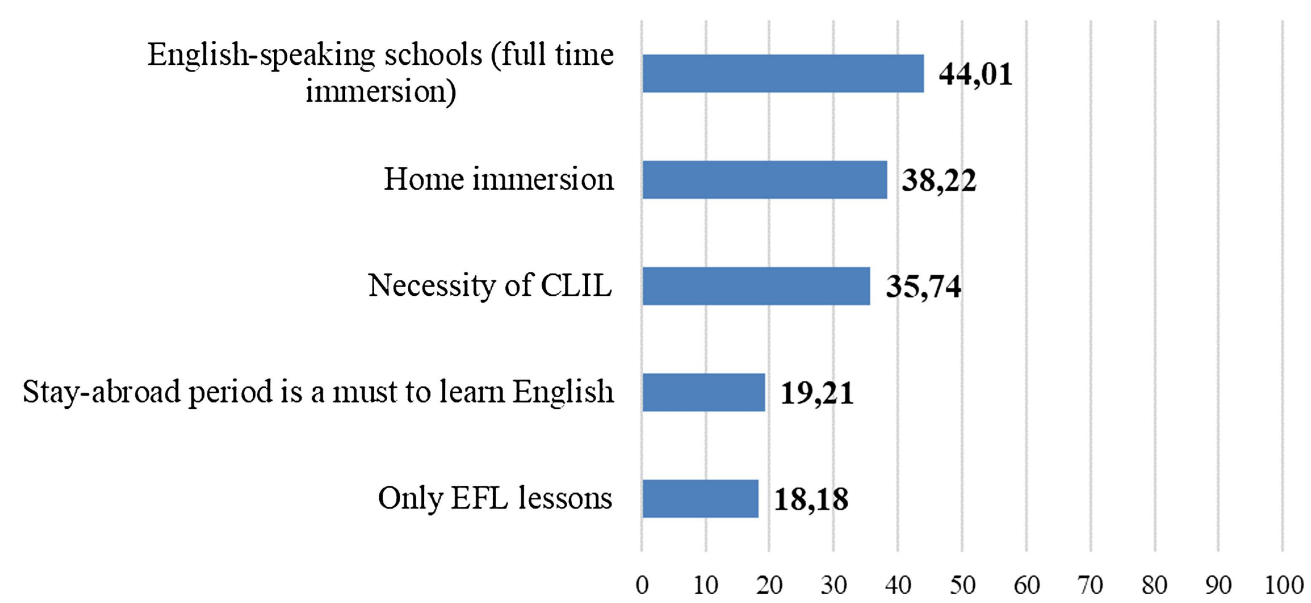

Concerning the sixth thematic strand, which is centred on teachers' professional development or the skills and qualifications needed to be an ideal teacher in multilingual programmes, Figure 6 reveals that just 14 teacher trainees out of 121 (i.e. $11.5 \%$ ) state that the ideal EAL teacher should be a native speaker $(M=28.93$; SD $=21.41)$. However, while $87.6 \%$ of respondents advocate for increasing primary teachers' linguistic competence in English $(M=76.24 ; S D=19.05)$, only $42.1 \%$ of the sample support the convenience of preschool teachers reaching an advanced proficiency level $(M=51.45 ; S D=28.74)$.

Figure 6. Means of teachers' beliefs about the teacher profile (6th thematic strand).

\section{The teacher's profile}

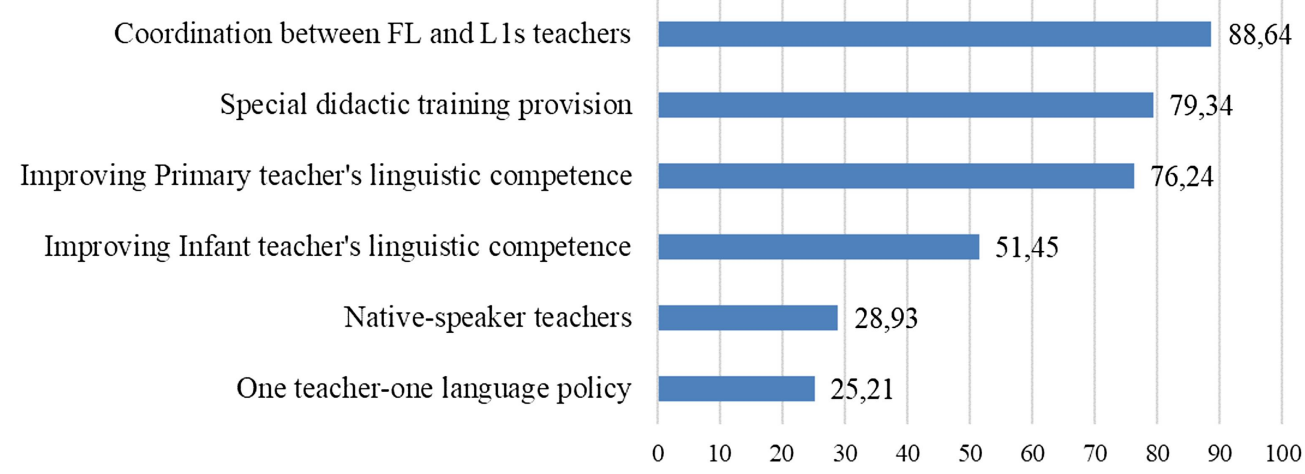

As regards teacher training in multilingual education, most respondents (90.9\%) welcome the provision of further didactic preparation especially in the multilingual factor $(M=79.34 ; S D=15.02)$. It is also worth noting that participants in the study agree on working towards an integrated and coordinated approach to languages $(M=88.64 ; S D=12.91)$. Accordingly, most of them question language separation and the one teacher-one language policy preferred in monolingual views of language teaching $(M$ $=25.21 ; \mathrm{SD}=24.89$ ). Those results contradict the findings reported by De Angelis (2011) and Otwinowska (2014) because inservice teachers in these studies were reluctant to bring other languages to the classroom and preferred the exclusive use of the target language. Although we cannot be certain about whether our pre-service teachers would apply principles based upon coordination and inclusion of students' whole linguistic repertoires in their actual EAL classroom practices, the present study was designed to ascertain the effect of coursework on their pre-existing beliefs discussed so far. 
The second Research Question was posed to examine the impact of instruction on prospective subject teachers' beliefs in multilingual pedagogies, that is, whether, as Kagan puts it (1992, p. 154), 'candidates tend [...] to confirm rather than confront and correct' them. As explained in the Method section, the instrument employed in order to measure such beliefs was implemented as a pretest and as a posttest. In between, the students received eighteen hours of lectures devoted to deal with the multilingual factor in current language pedagogies. To start this analysis, a paired-samples $t$-test was conducted to compare the global means before and after instruction.

As seen in Table 1 above, there was a significant difference in the scores for the pretest $(M=366.679$, SD $=35.04)$ and the posttest $(M=400.59, S D=42.15) ; t(120)=-9.304, p=0.000$. This change suggests that student teachers' beliefs are sensitive to training. While, prior to instruction, a number of unrealistic or naive perceptions about teaching and learning in multilingual contexts were documented, replies to the posttest were more aligned with the premises and principles of multilingualism. Hence, increasing our awareness of teacher trainees' pre-existing beliefs seems paramount to design effective multilingual didactic courses that may debunk those assumptions based on misconceptions or myths. As highlighted by Bruner (1996, p. 46), new input will need to 'compete with, replace or otherwise modify the folk theories that already guide them'.

Table 1. Global scores in the pretest and the posttest.

\begin{tabular}{|l|c|c|c|}
\hline GLOBAL SCORES & Mean & SD & Test statistics \\
\hline Pre-test & 366.679 & 35.04 & $t(120)=-9.304$ \\
\hline Postest & 400.59 & 42.15 & $p=0.000$ \\
\hline
\end{tabular}

Note: Paired-samples $t$-test results.

Beyond confirming the benefits of initial teacher training, we were also interested in identifying where those differences between both tests actually lied. To that end, we compared the scores before and after tuition in each thematic strand by conducting $t$ tests (see Table 2).

Table 2. Mean scores and standard deviations of each thematic strand in the pretest and the posttest.

\begin{tabular}{|c|c|c|c|}
\hline & $\begin{array}{c}\text { PRETEST } \\
\text { (means and standard deviations) }\end{array}$ & $\begin{array}{c}\text { POSTEST } \\
\text { (means and standard deviations) }\end{array}$ & Test statistics \\
\hline STRAND 1 & 48.38 (14.83) & 54.29 (13.35) & $\begin{array}{c}t(120)=-4.4490, \\
p=0.000\end{array}$ \\
\hline STRAND 2 & 68.07 (13.35) & $68.28(13.43)$ & $\begin{array}{c}t(120)=-.166 \\
p=0.868\end{array}$ \\
\hline STRAND 3 & 70.91 (12.62) & 78.72 (13.14) & $\begin{array}{c}t(120)=-6.252 \\
p=0.000\end{array}$ \\
\hline STRAND 4 & 40.78 (9.10) & $43.11(13.36)$ & $\begin{array}{c}t(120)=-1.644 \\
p=0.103\end{array}$ \\
\hline STRAND 5 & 68.92 (11.40) & 77.56 (10.76) & $\begin{array}{c}t(120)=-6.315 \\
p=0.000\end{array}$ \\
\hline STRAND 6 & 73.58 (9.88) & 78.61 (10.17) & $\begin{array}{c}t(120)=-5.053 \\
p=0.000\end{array}$ \\
\hline
\end{tabular}

Note: Paired-samples $t$-test results.

As can be gathered from the $p$-values coloured in red, Table 2 shows how the impact of instruction was statistically significant in all the thematic strands, with two exceptions. Significant changes were found when comparing the means of the pretest and posttest in strand number $1(t(120)=-4.4490, p=0.000)$, number $3(t(120)=-6.252, p=0.000)$, number $5(t(120)=-7.368, p=$ $0.000)$ and number $6(t(120)=-5.053, p=0.000)$. However, no significant differences appeared in the thematic strands number 2 $(t(120)=-.166, p=0.868)$ and number $4(t(120)=-1.644, p=0.103)$. Thus, the impact of training through coursework was positive and effective in all the thematic strands, aside from number 2 (i.e. ways of enhancing multilingual education) and number 4 (i.e. early foreign language learning).

Concerning the second thematic strand, the impact of instruction proves limited when respondents still voice reservations about teaching migrant and/or non-European languages in their posttests. With respect to thematic strand 4 , the 'younger = better' premise is also difficult to change. Despite having explained how wrong is attributing the apparent success and higher speed of children's language learning process to the existence of some physiological advantages or neurobiological features, most 
subjects still believe that kindergarteners are like sponges. Such persistence may be linked to the role played by a number of external factors other than instruction on belief formation and maintenance. The influence of mass media campaigns in support of the early introduction of English, for instance, should be counted among them. Hence, instruction loses effectiveness in the most mediatic or controversial issues, such as the earlier the better or the introduction of migrant languages in the school curriculum.

Additionally, posttest results indicate that pre-service teachers' beliefs are mainly informed by multilingual views (with values superior to 65\%) in most of the thematic strands. Yet, some notions about multilingual policy in Europe (strand 1) and early foreign language learning (strand 4) show that a monolingual bias persists even after training, a finding shared with previous studies conducted in similar multilingual contexts (see Arocena-Egaña et al., 2015, pp. 188-189). Thus, it seems that the effects of instruction are not uniform. While teacher initial training is most effective in those issues with a clearer theoretical component (e.g. the notion of multicompetence), it does not reach those that are more sensitive to public opinion (e.g. the earlier, the better fallacy).

\section{Conclusion}

This article set out (i) to identify novice subject teachers' beliefs in teaching EAL at preschool and primary educational levels, and (ii) to explore the effectiveness of instruction through an undergraduate 24-hour course. Data from the current study, collected through a Likert scale questionnaire, show both similarities and differences with previous research, mostly centred on experienced language secondary teachers (see De Angelis, 2011; Griva \& Chostelidou, 2012; Haukås, 2016; Heyder \& Schädlich, 2014; Mitits, 2018; or, Otwinowska, 2014).

In addressing the first research question (i.e. the description of participants' pre-existing views), we might conclude that Valencian subject teacher trainees' beliefs are dependant on individual factors, such as their linguistic background. This would explain why our respondents envision a European multilingual policy based, not only on introducing foreign languages other than English (equally supported by Greek teachers in Griva \& Chostelidou's, 2012 study), but also on a stronger promotion of minority languages like Catalan, which is the mother tongue for $53.7 \%$ of them.

Another conclusion to be drawn is that some of our student teachers' beliefs still suffer from a monolingual bias, already traced in prior studies conducted in similar multilingual contexts (e.g. Arocena-Egaña et al., 2015). For instance, the term multicompetence is wrongly defined as the result of attaining very high proficiency levels in all the languages a multilingual speaker uses, a misconception that has to do with the pervasiveness of the native speaker fallacy.

Precisely, the second objective of this paper was to ascertain whether assumptions of this type were sensitive to instruction. The answer to this second research question is that they are, although the effects of initial teacher training are unequal. While instruction is positive in shaping pre-service teachers' beliefs when they are linked to academic or research-based principles (strands 1, 3, 5 and 6), those subject to societal tendencies (re-)produced in the mass media (strands 2 and 4) have proven more resistant to change.

Clearly, this is a study with a number of limitations both in terms of representativeness of the sample and data reliability. The use of a questionnaire based on participants' reported beliefs might have provided overly positive replies to please the researcher. Eliciting beliefs is very complex since they are not directly observable. A follow-up study of this same sample would doubtlessly throw more light on two aspects that have remained unexplored here. First, to investigate the impact of variables other than instruction, such as previous schooling or the potential role of teacher degree specialisation. Second, to complement the current analysis of teacher trainees' beliefs with an examination of their future in-class interaction in order to ascertain the correspondence between beliefs and actual behaviour. All in all, our findings confirm a shift toward greater alignment in beliefs with principles of multilingual education research; and, most importantly, that change is possible when initial teacher training programmes deal with the multilingual factor.

\section{Acknowledgements}

As members of LAELA (Lingüística Aplicada a l'Ensenyament de la Llengua Anglesa) research group at Universitat Jaume I (Castelló, Spain), we would like to acknowledge that this study is part of a research project funded by (a) the Spanish Ministerio de Economia y Competitividad (FFI2016-78584-P), (b) the Universitat Jaume I (P1-1B2015-20, E-2015-03 and E-2015-30) and (c) Projectes d'Innovació Educativa de la Unitat de Suport Educatiu 3457/17.

\section{Disclosure statement}

No potential conflict of interest was reported by the authors[AQ10].

\section{ORCID}

Laura Portolés http://orcid.org/0000-0003-2916-7069

Otilia Martí http://orcid.org/0000-0002-7749-5238

\section{References}

Abasifar, S., \& Fotovatnia, Z. (2015). Impact of teacher training course on Iranian EFL teachers' beliefs. International Journal of Foreign Language Teaching \& Research, 3(9), 63-75.[AQ11] 
Alcón-Soler, E. (2012). Teachability and bilingualism effects on third language learners' pragmatic knowledge. Intercultural Pragmatics, 9(4), 511-541.

Arocena-Egaña, E., Cenoz, J., \& Gorter, D. (2015). Teachers' beliefs in multilingual education in the Basque country and in Friesland. Journal of Immersion and Content-Based Language Education, 3(2), 169-193.

Borg, S. (2003). Teacher cognition in language teaching: A review of research on what language teachers think, know, believe, and do. Language Teaching, 36(2), 81-109.

Borg, S. (2011). The impact of in-service teacher education on language teachers' beliefs. System, 39, 370-380.

Bruner, J. (1996). The culture of education. Cambridge, MA: Harvard University Press.

Cabaroglu, N., \& Roberts, J. (2000). Development in student teachers' pre-existing beliefs during a 1-year PGCE programme. System, 28(3), 387-402.

Cenoz, J. (2017). Translanguaging in school contexts: International perspectives. Journal of Language, Identity \& Education, 16(4), 193-198.

Cenoz, J., \& Gorter, D. (2015). Towards a holistic approach in the study of multilingual education. In J. Cenoz \& D. Gorter (Eds.), Multilingual education. Between language learning and translanguaging (pp. 2-15). Cambridge: Cambridge University Press.

Cenoz, J., \& Gorter, D. (2017). Translanguaging as a pedagogical tool in multilingual education. In J. Cenoz, D. Gorter, \& S. May (Eds.), Language awareness and multilingualism. Encyclopedia of language and education (3rd ed., pp. 309-321). Cham: Springer. doi:10.1007/978-3-319-02240-6_20

Cook, V. J. (1991). The poverty-of-the-stimulus argument and multicompetence. Second Language Research, 7(2), $103-117$.

Cook, V. J. (1992). Evidence for multi-competence. Language Learning, 42(4), 557-591.

Cook, V. J. (2007). The goals of ELT: Reproducing native-speakers or promoting multicompetence among second language users? In J. Cummins \& C. Davison (Eds.), International handbook of English language teaching (pp. 237-248). New York: Springer.

Davies, A. (2003). The native speaker: Myth and reality. Bristol: Multilingual Matters.

De Angelis, G. (2011). Teachers' beliefs about the role of prior language knowledge in learning and how these influence teaching practices. International Journal of Multilingualism, 8(3), 216-234.

Debreli, E. (2012). Change in beliefs of pre-service teachers about teaching and learning English as a foreign language throughout an undergraduate pre-service teacher training program. Procedia - Social and Behavioral Sciences, 46, 367-373.

García, O., \& Wei, L. (2014). Translanguaging: Language, bilingualism and education. New York: Palgrave Macmillan.

Griva, E., \& Chostelidou, D. (2012). Multilingual competence development in the Greek educational system: FL teachers' beliefs and attitudes. International Journal of Multilingualism, 9(3), 257-271.

Haukås, Å. (2016). Teacher's beliefs about multilingualism and a multilingual pedagogical approach. International Journal of Multilingualism, 13(1), 1-18.

Heyder, K., \& Schädlich, B. (2014). Mehrsprachigkeit und Mehrkulturalität —eine Umfrage unter Fremdsprachenlehrkräften in Niedersachsen. Zeitschrift für Interkulturellen Fremdsprachenunterricht, 19(1), 183-201.

Inbar-Lourie, O. (2010). English only? The linguistic choices of teachers of young EFL learners. International Journal of Bilingualism, 14(3), 351-367.

Kagan, D. (1992). Professional growth among preservice and beginning teachers. Review of Educational Research, 62(2), 129-169.

Karavas, E., \& Drossou, M. (2010). How amenable are student teacher beliefs to change? A study of EFL student teacher beliefs before and after teaching practice. Advances in Research on Language Acquisition and Teaching: Selected Papers, 262-276.[AQ12]

Kirsch, C. (2017). Young children capitalising on their entire language repertoire for language learning at school. Language, Culture and Curriculum, 1-17. doi:10.1080/07908318.2017.1304954

Lewis, G., Jones, B., \& Baker, C. (2012). Translanguaging: Origins and development from school to street and beyond. Educational Research and Evaluation: An International Journal on Theory and Practice, 18(7), 641-654. doi:10.1080/13803611.2012.718488

Llurda, E. (2009). The decline and fall of the native speaker. In L. Wei \& V. Cook (Eds.), Contemporary applied linguistics: Language teaching and learning (Vol. 1, pp. 37-53). Oxford: Continuum.

Llurda, E. (2016). 'Native speakers', English and ELT. Changing perspectives. In G. Hall (Ed.), The Routledge handbook of ELT (pp. 51-63). London: Routledge.

Lortie, D. (1975). School teacher: A sociological study. Chicago: University of Chicago Press.

Martí, O., \& Portolés, L. (2016). Ensenyar anglés des d'una perspectiva plurilingüe: creences i coneixements previs del futur professorat d'educació infantil i primària. In A. Díez, V. Brotons, D. Escandell, \& J. R. Collado (Eds.), Aprenentatges plurilingües $i$ literaris. Nous enfocaments didàctics (pp. 139-148). Alacant: Publicacions de la Universitat d'Alacant[AQ13].

Mitits, L. (2018). Multilingual students in Greek school: Teachers' views and teaching practices. Journal of Education and e-Learning Research, 5(1), 28-36.

Otwinowska, A. (2014). Does multilingualism influence plurilingual awareness of Polish teachers of English? International Journal 
of Multilingualism, 11(1), 97-119.

Otwinowska, A. (2017). English teachers' language awareness: Away with the monolingual bias? Language Awareness, 26(4), 304-324.[AQ14]

Pajares, M. (1992). Teachers' beliefs and educational research: Cleaning up a messy construct. Review of Educational Research, 62, 307-332.

Peacock, M. (2001). Preservice ESL teacher' beliefs about second language learning: A longitudinal study. System, 29, $177-195$.

Portolés, L. (2014). Analysing prospective teachers' attitudes towards three languages in two different sociolinguistic and educational settings. In A. Otwinowska, \& G. De Angelis (Eds.), Teaching and learning in multilingual contexts: Sociolinguistic and educational perspectives (pp. 50-75). Clevedon: Multilingual Matters[AQ15].

Portolés, L. (2015). Multilingualism and very young learners: An analysis of pragmatic awareness and language attitudes. Boston: De Gruyter. doi:10.1515/9781501500022

Portolés, L., \& Martí, O. (2017). Translanguaging as a teaching resource in early language learning of English as a an additional language (EAL). Bellaterra Journal of Teaching \& Learning Language \& Literature, 10(1), 61-77. doi:10.5565/rev/jtl3.698

Richardson, V. (1996). The role of attitudes and beliefs in learning to teach. In J. Sikula (Ed.), Handbook of research on teacher education (2nd ed., pp. 102-119). New York: Macmillan.

Safont, P., \& Portolés, L. (2016). Pragmatic functions of formulaic speech in three different languages: A focus on early L3 learners of English. Journal of Immersion and Content-Based Language Education, 4(2), 225-250. 